\title{
Surveillance imaging in primary sclerosing cholangitis (PSC): evidence, patient preference and physician autonomy
}

\author{
Philip A. Berry, Sreelakshmi Kotha \\ Department of Gastroenterology, Guy's and St Thomas' Hospital, London, UK \\ Correspondence to: Philip A. Berry. Department of Gastroenterology, St Thomas' Hospital, Westminster Bridge Road, London SE1 7JD, UK. \\ Email: philaberry@hotmail.com. \\ Response to: Rabiee A, Silveira MG. Primary sclerosing cholangitis. Transl Gastroenterol Hepatol 2021;6:29.
}

Received: 14 July 2021; Accepted: 26 August 2021; Published: 25 October 2022.

doi: $10.21037 / \operatorname{tgh}-21-87$

View this article at: https://dx.doi.org/10.21037/tgh-21-87

Rabiee and Silveira's recent article on primary sclerosing cholangitis (PSC) comments on surveillance for cholangiocarcinoma, and highlights an area of ongoing controversy (1). They write, 'Though guidelines do not universally recommend surveillance for CCA a retrospective study including 79 patients with PSC who developed hepatobiliary cancer revealed that patients who underwent surveillance had a significantly improved 5-year survival compared to the nosurveillance group (68\% vs. 20\%).' Current guidelines in the United Kingdom advise a conservative approach, with magnetic resonance imaging (MRI) recommended only if clinical condition changes (2). Clinicians have argued against this, citing studies suggestive of clinical benefits from routine surveillance and contradictory advice from international societies (3).

As in other areas of medicine, decisions around surveillance need to take into account overall clinical and economic factors. If hundreds of thousands of patients with a certain condition require surveillance annually, the threshold at which this should commence will have a huge impact on resources. Correspondingly, a physician who elects to scan their patients annually because they interpret the evidence differently could be criticised. Despite this, there is enough latitude in most health systems for doctors and patients to settle on an approach that is comfortable for them. Given that PSC is rare, but carries a risk of cholangiocarcinoma in $10-15 \%$ of patients, the economic argument may be less relevant, justifying a more individualised approach.

During the COVID-19 pandemic the 'precautionary principle' has been used to justify the wearing of masks in the absence of strong evidence (4). The public are now more aware of the evidence-based practice and guidance, and of the difficulties that waiting for large, well-designed trials presents. Are present dangers and associated unknowns sufficient to overthrow evidencebased principles? What if we deny a generation of patients' surveillance now, but learn in ten years' time that lives could have been saved? And where do patients' preferences come into this debate?

Uncertainty about prognosis is associated with morbidity in PSC (5). Patients have expressed strong desires to the authors of this letter to have regular scans, in order to know how their disease is progressing and perhaps have some sense of control. Conversely, we know that surveillance can be associated with physical and psychological harms. Presently, hepatologists and patients are caught in a conflicted, uncertain zone; together they must find a path between guidance, patient preference and physician autonomy. While research continues into the effectiveness of surveillance in PSC, patient preferences and the effect on well-being should be studied in parallel.

\section{Acknowledgments}

Funding: None.

\section{Footnote}

Provenance and Peer Review: This article was a standard submission to the journal. The article did not undergo external peer review. 
Conflicts of Interest: Both authors have completed the ICMJE uniform disclosure form (available at https://tgh.amegroups. com/article/view/10.21037/tgh-21-87/coif). The authors have no conflicts of interest to declare.

Ethical Statement: The authors are accountable for all aspects of the work in ensuring that questions related to the accuracy or integrity of any part of the work are appropriately investigated and resolved.

Open Access Statement: This is an Open Access article distributed in accordance with the Creative Commons Attribution-NonCommercial-NoDerivs 4.0 International License (CC BY-NC-ND 4.0), which permits the noncommercial replication and distribution of the article with the strict proviso that no changes or edits are made and the original work is properly cited (including links to both the formal publication through the relevant DOI and the license). See: https://creativecommons.org/licenses/by-nc-nd/4.0/.

doi: $10.21037 / \operatorname{tgh}-21-87$

Cite this article as: Berry PA, Kotha S. Surveillance imaging in primary sclerosing cholangitis (PSC): evidence, patient preference and physician autonomy. Transl Gastroenterol Hepatol 2022;7:43.

\section{References}

1. Rabiee A, Silveira MG. Primary sclerosing cholangitis. Transl Gastroenterol Hepatol 2021;6:29.

2. Chapman MH, Thorburn D, Hirschfield GM, et al. British Society of Gastroenterology and UK-PSC guidelines for the diagnosis and management of primary sclerosing cholangitis. Gut 2019;68:1356-78.

3. Hawken J, Appanna G, Portal AJ. Is it time for recommendations to reflect reality in PSC surveillance? Frontline Gastroenterol 2021;13:88-9.

4. Greenhalgh T, Schmid MB, Czypionka T, et al. Face masks for the public during the covid-19 crisis. BMJ 2020;369:m1435.

5. Ranieri V, Kennedy E, Walmsley M, et al. The Primary Sclerosing Cholangitis (PSC) Wellbeing Study: Understanding psychological distress in those living with PSC and those who support them. PLoS One 2020;15:e234624. 